Short Communication

Human and Medical Genetics

\title{
Influence of a genetic variant of CHAT gene over the profile of plasma soluble ChAT in Alzheimer disease
}

\author{
Patricia Fernanda Rocha-Dias ${ }^{1}$, Daiane Priscila Simao-Silva ${ }^{2,5}$, Saritha Suellen Lopes da Silva ${ }^{1}$, \\ Mauro Roberto Piovezan ${ }^{3}$, Ricardo Krause M. Souza ${ }^{4}$, Taher. Darreh-Shori ${ }^{5}$, Lupe Furtado-Alle ${ }^{1}$ \\ and Ricardo Lehtonen Rodrigues Souza ${ }^{1}$ (D)
}

\author{
${ }^{1}$ Universidade Federal do Paraná (UFPR), Centro Politécnico, Programa de Pós-Graduação em Genética, \\ Departamento de Genética, Curitiba, PR, Brazil. \\ ${ }^{2}$ Instituto de Pesquisa do Câncer (IPEC), Guarapuava, PR, Brazil. \\ ${ }^{3}$ Universidade Federal do Paraná (UFPR), Departamento de Neurologia, Hospital de Clínicas, \\ Curitiba, PR, Brazil. \\ ${ }^{4}$ Instituto de Neurologia de Curitiba (INC), Ambulatório de Distúrbios da Memória e Comportamento, \\ Demência e Outros Transtornos Cognitivos e Comportamentais, Curitiba, PR, Brazil. \\ ${ }^{5}$ Karolinska Institutet, Care Sciences and Society, Department of Neurobiology, Stockholm, Sweden.
}

\begin{abstract}
The choline acetyltransferase (ChAT) and vesicular acetylcholine transporter (VAChT) are fundamental to neurophysiological functions of the central cholinergic system. We confirmed and quantified the presence of extracellular ChAT protein in human plasma and also characterized ChAT and VAChT polymorphisms, protein and activity levels in plasma of Alzheimer's disease patients (AD; $N=112)$ and in cognitively healthy controls $(E C ; N=$ 118). We found no significant differences in plasma levels of ChAT activity and protein between AD and EC groups. Although no differences were observed in plasma ChAT activity and protein concentration among ChEl-treated and untreated AD patients, ChAT activity and protein levels variance in plasma were higher among the rivastigminetreated group (ChAT protein: $p=0.005$; ChAT activity: $p=0.0002$ ). Moreover, AD patients homozygous for SNP rs $1880676 A$ allele exhibited higher levels of ChAT activity. Considering this is the first study to report the influence of genetic variability of ChAT locus over ChAT activity in AD patients plasma, it opens a new set of important questions on peripheral cholinergic signaling in AD.
\end{abstract}

Keywords: ChAT, VAChT, dementia, cholinergic dysfunction, peripheral cholinergic signaling.

Received: December 28, 2019; Accepted: September 21, 2020.

The central cholinergic system plays a fundamental role in memory and learning mechanisms, and cholinergic deficit in Alzheimer's disease (AD) generates cognitive impairment (Bartus et al., 1982). The "cholinergic hypothesis" (Davies and Maloney, 1976) refer to the cholinergic deficits in AD and the inability to transmit neurologic impulses across brain synapses. The cholinesterases $(\mathrm{ChE})$ are a family of enzymes that catalyze the hydrolysis of acetylcholine (ACh) into choline and acetic acid, an essential process for the restoration of the cholinergic neuron. There are two cholinesterase types: acetylcholinesterase (AChE; EC 3.1.1.7) and butyrylcholinesterase (BChE; EC 3.1.1.8). Both enzymes participate in cholinergic neutrotransmission by hydrolyzing acetylcholine in the central and peripheral nervous systems (Pohanka, 2011). Based on deficits in AD, cholinesterase inhibitors (ChEIs) are the first-line drugs in the symptomatic treatment of $\mathrm{AD}$ by inhibiting cholinesterase, and thus resulting in increased synaptic levels of ACh neurotransmitter. Currently the most prescribed ChEIs are donepezil, galantamine and rivastigmine (Ferris et al., 2013).

Send correspondence to Ricardo Lehtonen Rodrigues Souza. Federal University of Paraná (UFPR), Centro Politécnico, Department of Genetics, Postgraduate Program in Genetics, P.O. box 19071, 81531980, Curitiba, PR, Brazil. E-mail address: lehtonen@ufpr.br.
Cholinergic dysfunction is characterized by severe reduction in the cholinergic enzyme choline acetyltransferase (ChAT), which is one of the key features of the brains of patients with $\mathrm{AD}$ (Boissière et al., 1997). ChAT is responsible for the biosynthesis of the cholinergic neurotransmitter and acetylcholine (ACh) (Lee et al., 2012). ChAT reversibly catalyzes the transfer of the acetyl group from acetyl-coenzyme A to a choline molecule. Subsequently, the cytoplasmic ACh is stored in synaptic vesicles by the vesicular acetylcholine transporter (VAChT), until its release into the synaptic cleft (Oda, 1999; Govindasamy et al., 2004).

ChAT and VAChT have an important role in neurophysiological functions, especially for a correct performance of the cholinergic system (Nordberg and Svensson, 1998), being encoded by the genes CHAT and $S L C 18 A 3$, respectively. The central cholinergic system influences a wide range of neurophysiological processes, including cognitive performance, arousal, sleep, movement and processing of visual information (Oda, 1999).

Wilcock et al. (1982) found a decrease in ChAT activity, in the temporal and frontal lobe in the AD brain (Wilcock et al., 1982). In patients with mild cognitive impairment (MCI), however, an upregulation of ChAT activity is reported in the hippocampus and frontal cortex (DeKosky et al., 2002). 
CHAT gene and protein expression are reduced in AD when compared with the controls group brain (GonzálezCastañeda et al., 2013). Low ChAT protein levels have been shown to correlate with the severity of AD assessed by neuropsychological measures (Baskin et al., 1999), as well as severity of neuropathological lesions (Davis et al., 1999).

ChAT is considered a cytosolic enzyme found in both neurons (Bellier and Kimura, 2011; Lee et al. 2012), and in several non-neuronal cells (Hersh and Peet, 1978; Sastry et al., 1981; Kawashima and Fujii, 2003). Recent studies provide evidences for the presence of ChAT activity and protein in extracellular fluids, such as human plasma and cerebrospinal fluid (Vijayaraghavan et al., 2013), reformulating the concept that ChAT acts only as a cytosolic enzyme, located in cholinergic terminals (Oda,1999; Govindasamy et al., 2004).

In this study both, activity and the protein concentration of ChAT were measured in plasma samples of a patients with $\mathrm{AD}$ and control group of a Brazilian cohort, composed by 230 plasma samples of Brazilian individuals (112 cases with clinical diagnoses of AD and 118 cognitively normal elderly controls (EC), predominantly euro descendants). The samples were from the Cognitive Dysfunction Ambulatory from Clinical Hospital of the Federal University of Parana (HC-UFPR) and Disorders Clinic Memory and Behavior (ADEMEC) of Curitiba Neurology Institute (INC).

The diagnostic criteria for patients with $\mathrm{AD}$ followed the NINCDS-ADRDA standards (National Institute of Neurological and Communicative Disorders and Stroke-Alzheimer's disease and Related Disorders Association; McKhann et al. (2011), with adaptations of the recommendations of the Scientific Department of Neurology cognitive and aging of the Brazilian Academy of Neurology (Frota et al., 2011). Exclusion criteria for $\mathrm{AD}$ were: other forms of dementia, other psychiatric disorders, changes in recommended subsidiary exams, or any evidence or suspicion of inflammatory or infectious CNS disease.

Patients of the control group were excluded if they had infectious diseases (hepatitis, malaria, Chagas disease, HIV), were alcoholics, had previous history of stroke or loss of memory lapse, unable to perform daily life activities, had persistent complaints about memory and depressive symptoms.

In the current study, the global cognition was assessed by the Mini-Mental State Examination tests, MMSE (Folstein et al., 1975), while the stage of the disease was determined by the Clinical Dementia Rating scale, CDR (Morris, 1993). The patients with $\mathrm{AD}$, and/or their kin or legal guardians, as well as the patients of the control group, were informed about the research, and if agreed, signed the Term of Freeinformed to participate in the study. The project was approved by Ethics Committee of the Federal University of Parana, Health Sciences Sector.

We also determined the genetic polymorphism in the cholinergic locus (the rs3810950, rs 733722, and rs 1880676 for $C H A T$ ) and $r s 2269338$ for the SLC18A3 gene (VAChT). Then we investigated whether these genetic variants influence ChAT profiles in the plasma samples of this Brazilian cohort, in relation to education, cognitive performance and the use of cholinesterase inhibitors (ChEIs).
Genotyping was performed by TaqMan SNP Genotyping Assays (Applied Biosystems) in a ViiA 7 Real-Time PCR System (Thermofisher Scientific). For this, the total genomic DNA was extracted from peripheral blood by a salting out method (Lahiri and Nurnberger Jr, 1991) (with modifications) and diluted to a final concentration of $20 \mathrm{ng} / \mu \mathrm{L}$. The PCR conditions used for each individual SNP were composed of 5 $\mu \mathrm{L}$ TaqMan Universal PCR Master Mix, $0.5 \mu \mathrm{L}$ of the specific SNP probes included in each TaqMan Kit, $2.5 \mu \mathrm{L}$ of ultrapure water and $2 \mu \mathrm{L}$ DNA $20 \mathrm{ng} / \mu \mathrm{L}$, having a final volume of 10 $\mu \mathrm{L}$. The PCR cycles were $60 \mathrm{~s}$ at $60{ }^{\circ} \mathrm{C} ; 10 \mathrm{~min}$ at $95{ }^{\circ} \mathrm{C} ; 50$ times 15 cycles at $95{ }^{\circ} \mathrm{C}$ alternated with $90 \mathrm{~s}$ at $60{ }^{\circ} \mathrm{C}$; and a final step of 30 sat $60^{\circ} \mathrm{C}$.

To determine the levels of ChAT in plasma we performed an integrated enzyme activity-sandwich ELISA-(Enzyme Linked Immunosorbent Assay) set up as described previously (Vijayaraghavan et al., 2013). These analyses were done at Karolinska Instituted, the Department of Neurobiology, Care Sciences and Society, Stockholm, Sweden.

Nortest package R program was used to test for normality (Shapiro-Wilk test with Lilliefors correction) of the variables activity and protein concentration, MMSE and years of study. After analyzing the distributions, comparisons were made by means of the $t$ test or Mann-Whitney for parametric and nonparametric variables, respectively, as well as multiple regression analysis. Variances were compared by the Bartlett test. The confidence interval for all statistical analyzes was $95 \%(\mathrm{p}=0.05)$.

The demographic data of the $\mathrm{AD}$ patients and the $\mathrm{EC}$ are presented in Table 1 . The mean age was significantly different between patients with AD and EC. This is due to the difficulty related to finding cognitively healthy volunteers following the exclusion criteria described in the method section. The MMSE data corroborate an expected difference between AD and EC groups. The EC group had more years of education, most likely reflecting the younger pattern of age among the EC group. Approximately $90 \%(n=101)$ of the AD patients underwent pharmacological treatment for dementia, and about $70 \%(\mathrm{n}=71)$ of the AD medication was ChEIs.

The median together with $1^{\text {st }}$ and $3^{\text {rd }}$ quartiles values of the protein concentration and activity of ChAT in the plasma samples of AD patients and EC is presented in Table 2. No significant difference between the groups was observed.

Unlike the ChAT levels in the brain of patients with $\mathrm{AD}$, the plasma pattern of ChAT is not known, so this is the first report on ChAT levels and how they differed in the brain (Boissière et al., 1997). The relation between peripheral ChAT and $\mathrm{AD}$ is established by the classical neurotransmitter ACh. This molecule acts as a suppressor of inflammatory responses of lymphocytes (Parrish et al., 2008), and the major sources of extracellular ChAT in the plasma might be lymphocytes (Vijayaraghavan et al., 2013). The systemic immunity is modulated by the cholinergic anti-inflammatory pathway (Pavlov et al., 2009) and the cholinergic transmission in turn cause low-degree systemic inflammation in DA (DarrehShori, et al. 2009). Therefore, a hypothesis would be to alter the expression levels of ChAT, just as it occurs in the brain. In this study for the patients with $\mathrm{AD}$, the peripheral level of ChAT concentration may have been influenced by 
Table 1 - Demographics and characteristics of Alzheimer patients (AD) and elderly controls (EC).

\begin{tabular}{lccc}
\hline & $\mathrm{AD}$ & $\mathrm{EC}$ \\
& $\mathrm{N}=112$ & $\mathrm{~N}=118$ & $\mathrm{p}$ \\
\hline Age & Median & Median \\
MMSE & $79(73-84)$ & $71(66-76)$ & $5.8 \mathrm{e}-8$ \\
Education* & $15(6.75-20)$ & $27(26-29)$ & $2.2 \mathrm{e}-16$ \\
Female (F) & $4(2-8)$ & $4(4-11)$ & 0.027 \\
Male (M) & $60.7 \%$ & $72.9 \%$ & 0.049 \\
AD Treatment & $39.3 \%$ & $27.1 \%$ & \\
ChEIs & $89.3 \%$ &.- & \\
\hline
\end{tabular}

* years of study.

Table 2 - Protein and activity of soluble choline acetyltransferase (ChAT) in plasma of patients with AD and elderly controls (EC).

\begin{tabular}{lccc}
\hline & AD N=112 & EC N=118 & AD x EC \\
\hline & $\begin{array}{c}\text { Median } \\
\text { (1st quartile }-3 \text { rd quartile) }\end{array}$ & $\begin{array}{c}\text { Median } \\
\text { (1st quartile }-3 \text { rd quartile) }\end{array}$ & p \\
\hline $\begin{array}{l}\text { Plasma ChAT protein }(\mu \mathrm{g} / \mathrm{mL}) \\
\begin{array}{l}\text { Plasma ChAT activity }(\mathrm{nmol} / \\
\text { min/mL) }\end{array}\end{array}$ & $96.74(55.07-139.94)$ & $85.73(58.17-118.64)$ & 0.46 \\
\hline
\end{tabular}

the action of IChEs, since the enzyme is modulated by the bioavailable Ach concentration. Possibly the changes caused in the inflammatory pathway do not change the peripheral ChAT synthesis.

These data were analyzed with respect to ChAT gene polymorphism profiles, presented in Table 3. Among the AD group, a significant difference was observed in the plasma ChAT activity with respect to the SNP, $r s 1880676$. The AD carriers of the G allele had significantly lower plasma ChAT activity than the non-carrier AD group $(p=0.002$, Table 3$)$.

No differences were observed in ChAT activity $(\mathrm{p}=$ $0.67)$ and ChAT protein concentration in plasma $(\mathrm{p}=0.79)$ between patients with and without treatment with CHEIs. However, separating by type of treatment (Figure 1), although means do not differ, the variance of the group that used rivastigmine is higher (ChAT protein: $p=0.005$; ChAT activity: $p=0.0002$ ).

About $70 \%$ of the AD patients, included in the current study, were on treatment with the ChEIs, which are the main therapeutic option available today. Currently, there is no information on how treatment with ChEIs may affect the levels of soluble ChAT in plasma, cerebrospinal fluid or the brain. Therefore, the lack of difference between the plasma ChAT levels among the AD and the controls could be due to an increase in ChAT levels in plasma, possibly induced by treatment with ChEIs. This is because ChEIs are expected to alter ACh homeostasis by inhibiting degradation of ACh by cholinesterases in circulation (Vijayaraghavan et al.,
2013). The plasma ChAT levels between the AD patients who were on ChEIs therapy, compared to those who were not, partially supported the above notion, since the variance of ChAT was different in those taking rivastigmine, which indicates a bidirectional influence of this drug on ChAT protein expression in the plasma. This is interesting since $\mathrm{BChE}$ activity dominates in plasma, and rivastigmine is the only ChEI as AD therapeutic that inhibits both AChE and BChE with equal efficacy (Darreh-Shori et al., 2002). In whole-blood circulation, AChE activity dominates as attached on the outer cell membrane of the red blood cells (RBC), and BChE as soluble enzyme in plasma fluid. In case of donepezil and galantamine treatments, mainly RBC AChE activity is inhibited by about $30-40 \%$ (Darreh-Shori et al., 2006, 2008). Thus the unaffected plasma BChE is more than enough to compensate since these two ChEIs have negligible activity on plasma BChE (Darreh-Shori et al., 2006, 2008). In contrast, rivastigmine inhibits both $\mathrm{AChE}$ and $\mathrm{BChE}$ with over $40 \%$ at the recommended dosage (Darreh-Shori et al., 2002). In addition the efficacy of inhibition by rivastigmine can greatly vary in different patients depending on variables such as tolerated dose and body weight, which in turn result in a large variation in the inhibition levels of these two enzymes. This could express itself in a wide variation in the plasma ChAT expression as was seen among the rivastigmine-treated patients. More studies are however required to confirm and expand the current findings. 
Table 3 - Comparisons between the median of ChAT protein concentration and activity in plasma, grouped by carrier and not allele carrier, for each specific SNP (rs3810950, rs2269338, rs1880676 and rs733722) from (ADxAD; ECxEC).

\begin{tabular}{|c|c|c|c|c|c|c|}
\hline \multirow[t]{2}{*}{$r s 3810950$} & \multicolumn{3}{|c|}{$\mathrm{AD}$} & \multicolumn{3}{|c|}{$\mathrm{EC}$} \\
\hline & $\begin{array}{c}\text { Carrier } \mathrm{G}(\mathrm{AG}+\mathrm{GG}) \\
\mathrm{N}=99\end{array}$ & $\begin{array}{l}\text { Not Carrier (AA) } \\
\qquad N=5\end{array}$ & $\mathrm{p}$ & $\begin{array}{c}\text { Carrier } \mathrm{G}(\mathrm{AG}+\mathrm{GG}) \\
\mathrm{N}=81\end{array}$ & $\begin{array}{l}\text { Not Carrier (AA) } \\
\qquad N=6\end{array}$ & $\mathrm{p}$ \\
\hline ChAT protein & 91.70 & 148.87 & 0.23 & 81.53 & 54.24 & 0.10 \\
\hline ChAT activity & 33.29 & 39.78 & 0.52 & $28.24 \backslash$ & 19.83 & 0.48 \\
\hline \multirow[t]{2}{*}{ rs 1880676} & \multicolumn{3}{|c|}{$\mathrm{AD}$} & \multicolumn{3}{|c|}{$\mathrm{EC}$} \\
\hline & $\begin{array}{c}\text { Carrier } \mathrm{G}(\mathrm{AG}+\mathrm{GG}) \\
\mathrm{N}=98\end{array}$ & $\begin{array}{l}\text { Not Carrier (AA) } \\
\qquad N=5\end{array}$ & $\mathrm{p}$ & $\begin{array}{c}\text { Carrier } \mathrm{G}(\mathrm{AG}+\mathrm{GG}) \\
\mathrm{N}=78\end{array}$ & $\begin{array}{l}\text { Not Carrier (AA) } \\
\qquad N=7\end{array}$ & $\mathrm{p}$ \\
\hline ChAT protein & 91.53 & 148.87 & 0.24 & 80.97 & 47.52 & 0.05 \\
\hline ChAT activity & 33.58 & 39.78 & 0.002 & 27.68 & 28.36 & 0.78 \\
\hline \multirow[t]{2}{*}{$r s 733722$} & \multicolumn{3}{|c|}{$\mathrm{AD}$} & \multicolumn{3}{|c|}{$\mathrm{EC}$} \\
\hline & $\begin{array}{c}\text { Carrier G (GT+GG) } \\
\qquad \mathrm{N}=93\end{array}$ & $\begin{array}{l}\text { Not Carrier (TT) } \\
\qquad \mathrm{N}=9\end{array}$ & $\mathrm{p}$ & $\begin{array}{c}\text { Carrier G }(\mathrm{GT}+\mathrm{GG}) \\
\mathrm{N}=84\end{array}$ & $\begin{array}{l}\text { Not Carrier (TT) } \\
\qquad \mathrm{N}=3\end{array}$ & $\mathrm{p}$ \\
\hline ChAT protein & 96.28 & 90.85 & 0.42 & 77.47 & 101.36 & 0.96 \\
\hline ChAT activity & 33.59 & 30.22 & 0.84 & 28.32 & 31.91 & 0.32 \\
\hline \multirow[t]{2}{*}{$r s 2269338^{*}$} & \multicolumn{3}{|c|}{$\mathrm{AD}$} & \multicolumn{3}{|c|}{$\mathrm{EC}$} \\
\hline & $\begin{array}{c}\text { Carrier G (GT+GG) } \\
\mathrm{N}=102\end{array}$ & $\begin{array}{l}\text { Not Carrier (TT) } \\
\qquad \mathrm{N}=3\end{array}$ & $\mathrm{p}$ & $\begin{array}{c}\text { Carrier G (GT+GG) } \\
\mathrm{N}=86\end{array}$ & $\begin{array}{l}\text { Not Carrier (TT) } \\
\qquad \mathrm{N}=2\end{array}$ & $\mathrm{p}$ \\
\hline ChAT protein & 91.70 & 206.24 & 0.08 & 77.47 & 224.10 & 0.09 \\
\hline ChAT activity & 32.51 & 45.33 & 0.12 & 28.32 & 5.85 & 0.12 \\
\hline
\end{tabular}

ChAT protein concentration is in $\mathrm{ng} / \mathrm{mL}$ and the enzyme activity in $\mathrm{nmol} / \mathrm{min} / \mathrm{ml}$. The SNP rs 3810948 was not included because it presents almost all the samples only one genotype. *The SNP, rs2269338 is in the SLC18A3 gene, commonly known as VACHT gene (vesicular acetylcholine transporter).

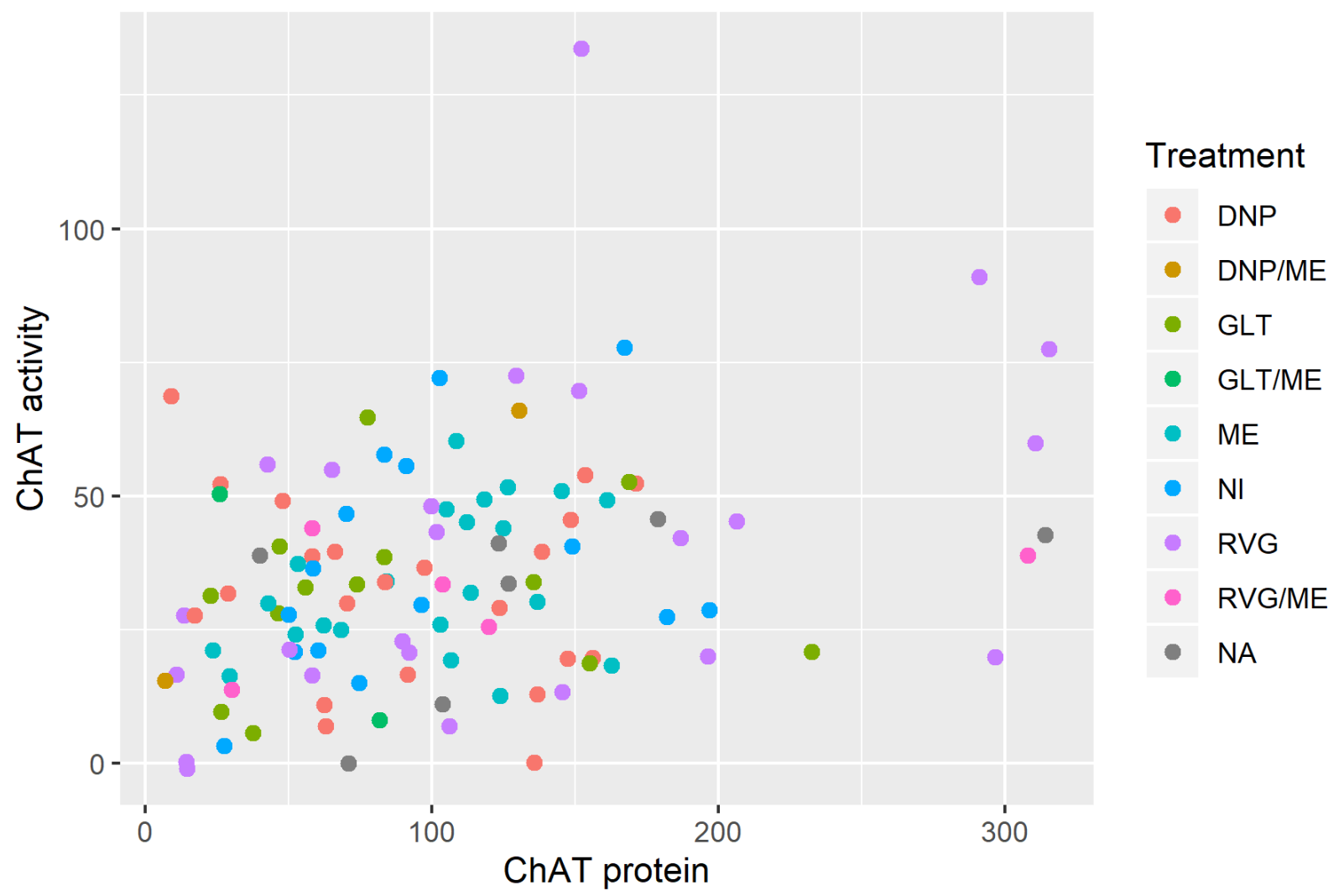

Figure 1 - Comparisons of the ChAT protein and activity of soluble ChAT in plasma of patients with Alzheimer's disease (AD), according to the treatment type. NA: no information; NI: do not use medicine; ME: memantine; DNP: donepezil; GLT: galantamine; RVG: rivastigmine. 
In conclusion, we reaffirm the presence of ChAT in human plasma by measuring both protein and activity of this enzyme in a reasonably large number of samples from patients with $\mathrm{AD}$ and the control group. Albeit no difference between plasma levels of ChAT among the groups were observed, we found that the $r s 1880676$ SNP alters differentially the phenotypic profiles of ChAT activity and protein expression in the plasma of the AD patients. This is the first study to report the influence of genetic variant of the cholinergic locus with the profile of soluble ChAT in plasma. Overall, the findings warrant further studies since identification and understanding of factors that may influence the phenotypic profile of ChAT in plasma could be important for the understanding of the role of this soluble enzyme in the normal and pathological function of peripheral cholinergic signaling.

\section{Acknowledgements}

We thank the Coordenação de Aperfeiçoamento de Pessoal de Nível Superior (CAPES/PROAP - Finance Code 001) for financial support and for the scholarships provided to P.F.R.D.

\section{Conflict of Interest}

The authors declare that there is no conflict of interest that could be perceived as prejudicial to the impartiality of the reported research.

\section{Authors Contributions}

RLRS, LFA, PFRD, DSSS, conceived and the study; PFRD, DPSS, SSLS conducted the experiments; TDS, RLRS, PFRD, DPSS analyzed the data; PFRD, DPSS, RLRS, LFA, TDS wrote the manuscript; MRP, RKMS made the clinical diagnosis. All authors read and approved the final version.

\section{References}

Bartus RT, Dean R 3rd, Beer B and Lippa AS (1982) The cholinergic hypothesis of geriatric memory dysfunction. Science 217:408-414.

Baskin DS, Browning JL, Pirozzolo FJ, Korporaal S, Baskin JA and Appel SH (1999) Brain choline acetyltransferase and mental function in Alzheimer disease. Arch Neurol 56:1121-1123.

Bellier J-P and Kimura H (2011) Peripheral type of choline acetyltransferase: biological and evolutionary implications for novel mechanisms in cholinergic system. J Chem Neuroanat 42:225-235.

Boissière F, Faucheux B, Agid Y and Hirsch EC (1997) Choline acetyltransferase mRNA expression in the striatal neurons of patients with Alzheimer's disease. Neurosci Lett 225:169172.

Darreh-Shori T, Almkvist O, Guan ZZ, Garlind A, Strandberg B, Svensson A-L, Soreq H, Hellström-Lindahl E and Nordberg A (2002) Sustained cholinesterase inhibition in AD patients receiving rivastigmine for 12 months. Neurology 59:563-72.

Darreh-Shori T, Meurling L, Pettersson T, Hugosson K, HellströmLindahl E, Andreasen N, Minthon L and Nordberg A (2006) Changes in the activity and protein levels of CSF acetylcholinesterases in relation to cognitive function of patients with mild Alzheimer's disease following chronic donepezil treatment. J Neural Transm 113:1791-1801.
Darreh-Shori T, Kadir A, Almkvist O, Grut M, Wall A, Blomquist G, Eriksson B, Långström B and Nordberg A (2008) Inhibition of acetylcholinesterase in CSF versus brain assessed by 11C-PMP PET in AD patients treated with galantamine. Neurobiol Aging 29:168-84.

Darreh-Shori T, Modiri N and Nordberg A (2009) P1-163: Apolipoprotein E and Butyrylcholinesterase synergistically promote $\mathrm{Ab}$ peptides oligomerization. Alzheimers Dement 5:P225-P225.

Davies P and Maloney A (1976) Selective loss of central cholinergic neurons in Alzheimer's disease. Lancet 308:1403.

Davis KL, Mohs RC, Marin D, Purohit DP, Perl DP, Lantz M, Austin G and Haroutunian V (1999) Cholinergic markers in elderly patients with early signs of Alzheimer disease. JAMA 281:1401-1406.

DeKosky ST, Ikonomovic MD, Styren SD, Beckett L, Wisniewski S, Bennett DA, Cochran EJ, Kordower JH and Mufson EJ (2002) Upregulation of choline acetyltransferase activity in hippocampus and frontal cortex of elderly subjects with mild cognitive impairment. Ann Neurol 51:145-155.

Ferris S, Karantzoulis S, Somogyi M and Meng X (2013) Rivastigmine in moderately severe-to-severe Alzheimer's disease: Severe Impairment Battery factor analysis. Alzheimers Res Ther 5:63.

Folstein MF, Folstein SE and McHugh PR (1975) "Mini-mental state": A practical method for grading the cognitive state of patients for the clinician. J Psychiatr Res 12:189-198.

Frota NAF, Nitrini R, Damasceno BP, Forlenza O, DiasTosta E, da Silva AB, Herrera Junior E and Magaldi RM (2011) Critérios para o diagnóstico de doença de Alzheimer. Dement Neuropsychol 5:5-10.

González-Castañeda RE, Sánchez-González VJ, Flores-Soto M, Vázquez-Camacho G, Macías-Islas MA and Ortiz GG (2013) Neural restrictive silencer factor and choline acetyltransferase expression in cerebral tissue of Alzheimer's disease patients: A pilot study. Genet Mol Biol 36:025-036.

Govindasamy L, Pedersen B, Lian W, Kukar T, Gu Y, Jin S, AgbandjeMcKenna M, Wu D and McKenna R (2004) Structural insights and functional implications of choline acetyltransferase. J Struct Biol 148:226-235.

Hersh LB and Peet M (1978) Effect of salts on the physical and kinetic properties of human placental choline acetyltransferase. J Neurochem 30:1087-1093.

Kawashima K and Fujii T (2003) The lymphocytic cholinergic system and its biological function. Life Sci 72:2101-2109.

Lahiri DK and Nurnberger Jr JI (1991) A rapid non-enzymatic method for the preparation of HMW DNA from blood for RFLP studies. Nucleic Acids Res 19:5444.

Lee JJ, Jo SA, Park JH, Lee SB, Jo I, Huh Y, Youn JC, Jhoo JH, Park KU, Park SS et al. (2012) Choline acetyltransferase 2384G> a polymorphism and the risk of Alzheimer disease. Alz Dis Assoc Dis 26:81-87.

McKhann GM, Knopman DS, Chertkow H, Hyman BT, Jack Jr CR, Kawas CH, Klunk WE, Koroshetz WJ, Manly JJ, Mayeux R et al. (2011) The diagnosis of dementia due to Alzheimer's disease: recommendations from the National Institute on Aging-Alzheimer's Association workgroups on diagnostic guidelines for Alzheimer's disease. Alzheimers Dement 7:263-269.

Morris JC (1993) The Clinical Dementia Rating (CDR): current version and scoring rules. Neurology 43:2412-2414.

Nordberg A and Svensson A-L (1998) Cholinesterase inhibitors in the treatment of Alzheimer's disease. Drug Safety 19:465-480.

Oda Y (1999) Choline acetyltransferase: the structure, distribution and pathologic changes in the central nervous system. Pathol Int 49:921-937. 
Parrish WR, Rosas-Ballina M, Gallowitsch-Puerta M, Ochani M, Ochani K, Yang L-H, Hudson L, Lin X, Patel N, Johnson SM et al. (2008) Modulation of TNF release by choline requires alpha subunit nicotinic acetylcholine receptor-mediated signaling. Mol Med 14:567-574.

Pavlov VA, Parrish WR, Rosas-Ballina M, Ochani M, Puerta M, Ochani K, Chavan S, Al-Abed Y and Tracey KJ (2009) Brain acetylcholinesterase activity controls systemic cytokine levels through the cholinergic anti-inflammatory pathway. Brain Behav Immun 23:41-45.

Pohanka M (2011) Cholinesterases, a target of pharmacology and toxicology. Biomed Pap 155:219-229.

Sastry B, Janson V and Chaturvedi AK (1981) Inhibition of human sperm motility by inhibitors of choline acetyltransferase. J Pharmacol Exp Ther 216:378-384.
Vijayaraghavan S, Karami A, Aeinehband S, Behbahani H, Grandien A, Nilsson B, Ekdahl KN, Lindblom RP, Piehl F and DarrehShori T (2013) Regulated extracellular choline acetyltransferase activity - the plausible missing link of the distant action of acetylcholine in the cholinergic anti-inflammatory pathway. PLoS One 8:e65936.

Wilcock G, Esiri M, Bowen D and Smith C (1982) Alzheimer's disease: correlation of cortical choline acetyltransferase activity with the severity of dementia and histological abnormalities. J Neurol Sci 57:407-417.

Associate Editor: Filippo Pinto e Vairo

License information: This is an open-access article distributed under the terms of the Creative Commons Attribution License (type CC-BY), which permits unrestricted use, distribution and reproduction in any medium, provided the original article is properly cited. 